Ann. rheum. Dis. (1962), 21, 63.

\title{
METABOLISM OF TRYPTOPHAN IN RHEUMATOID ARTHRITIS
}

BY

ISOBEL M. BETT

Rheumatic Diseases Unit, Northern General Hospital, Edinburgh

Recently McMillan (1960) has reported the presence of increased amounts of 3-hydroxyanthranilic acid (3HAA) in the urine of patients suffering from rheumatoid arthritis. As shown in Fig. 1, 3HAA is a normal intermediate of tryptophan metabolism. McMillan found that excretion of this metabolite did not exceed $375 \mu \mathrm{g}$./day in normal subjects (mean $200 \mu \mathrm{g} . /$ day). In patients with rheumatoid arthritis, the range extended to 2,250 $\mu \mathrm{g}$./day, and the mean was $820 \mu \mathrm{g}$./day. McMillan also measured 3HAA excretion in three cases of osteo-arthritis, eighteen cases of other orthopaedic conditions, and 25 cases of miscellaneous diseases. Included in the latter were five patients with diseases

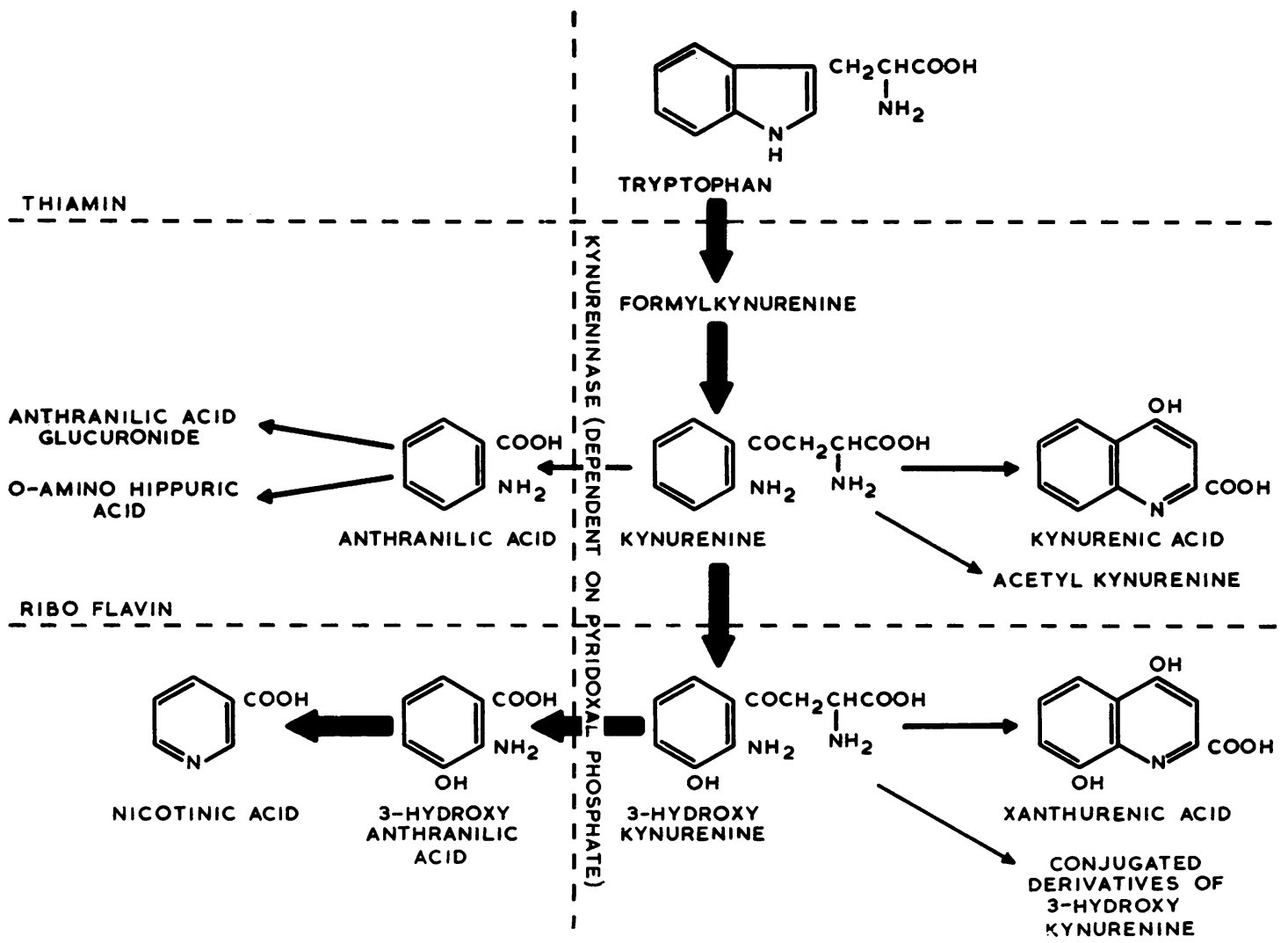

Fig. 1.-Abbreviated diagram of tryptophan catabolism via the kynurenine pathway, showing the stages at which some vitamins may participate (Dalgliesh, 1955). 
of the haemopoietic system and they tended to have raised outputs of 3HAA. No other disease, however, was investigated thoroughly in this study.

Oka and Leppänen (1959) also have suggested that the metabolism of tryptophan may be abnormal in rheumatoid arthritis. From chromatographic investigations of urinary indole excretion, they concluded that, in such patients, there might be some alteration in the metabolism of this amino acid, but via the kynurenine pathway.

Abnormalities of tryptophan metabolism accompanied by high urinary levels of 3HAA have been reported in a variety of diseases other than rheumatoid arthritis. The acid is known to be a carcinogen (Allen, Boyland, Dukes, Horning, and Watson, 1957) and high levels have been found in carcinoma of the bladder (Boyland and Williams, 1956; Tompsett, 1959a). An increased excretion of this metabolite has also been reported in pulmonary tuberculosis, Hodgkin's disease, and leukaemia (Musajo, Spada, and Coppini, 1952; Musajo, Benassi, and Parpajola, 1956). Other abnormalities of tryptophan metabolism have been reported in scleroderma (Price, Brown, Rukavina, Mendelson, and Johnson, 1957), hypoplastic anaemia (Altman and Miller, 1953), and diabetes (Wiseman, Kalant, and Hoffman, 1958). In these instances 3HAA was not measured.

Numerous methods have been described for isolating and measuring urinary metabolites of tryptophan, including 3HAA (Dalgliesh, 1952, 1955a, b; Boyland and Williams, 1956; Musajo and others, 1956; Tompsett, 1959a, 1961a; Coppini, Benassi, and Montorsi, 1959). When these are quantitative and include a control series, the results differ considerably from those obtained by McMillan.

In the investigation reported here, an attempt has been made to evaluate the semi-quantitative chromatographic method described by McMillan for measuring 3HAA, and subsequently to confirm her results. The study has been extended further to measure excretion of conjugated 3HAA by paper chromatography, and excretion of kynurenine, a higher degradation product of tryptophan, by an independent colorometric method. Data have also been obtained on the effect of loading doses of DL tryptophan and of its $D$ and $L$ isomers on the excretion of these metabolites.

\section{Material and Methods}

Urine was collected over 24-hr periods from patients with rheumatoid arthritis. Similar collections were obtained from a series of controls, including members of the staff of the Rheumatic Diseases Unit and otherwise healthy fracture cases in an orthopaedic ward. All measurements in the two series were made on aliquots of 24-hr collections of urine preserved by the addition of $15 \mathrm{ml}$. dilute sulphuric acid or $10 \mathrm{ml}$. concentrated hydrochloric acid. The administration of salicylates and other drugs was suspended during the collection $\stackrel{\vec{F}}{3}$ and for the $48 \mathrm{hrs}$ preceding.

\section{Measurement of 3HAA}

Activating and fluorescence spectra of solutions $\stackrel{\triangle}{\perp}$ containing 2 to $10 \mu \mathrm{g} . / \mathrm{ml}$. of the acid were determined $\cong$ in an Aminco Bowman spectrofluorimeter (Fig. $2 a$ and $b$ ). When these solutions were activated at $360 \mathrm{~m} \mu$, the emission at $450 \mathrm{~m} \mu$ was proportional to the concentration $\vec{\overrightarrow{ }}$ of acid. Attempts to measure 3HAA fluorimetrically ${ }_{\mathcal{O}}$ in extracts obtained from urine were unsuccessful. ฏ Whether obtained by ether or by absorption and elution 0 from de-activated charcoal or ion exchange resins, $\underset{\sim}{\sim}$ the extracts always contained interfering material or substances with activating and fluorescence spectra very oे $^{2}$ similar to those of 3HAA. Fluorimetry after one dimensional chromatography was also unsuccessful in $\mathrm{J}$ that elution without loss of fluorescence was difficult. Moreover, the blank values for paper and solvent were high.
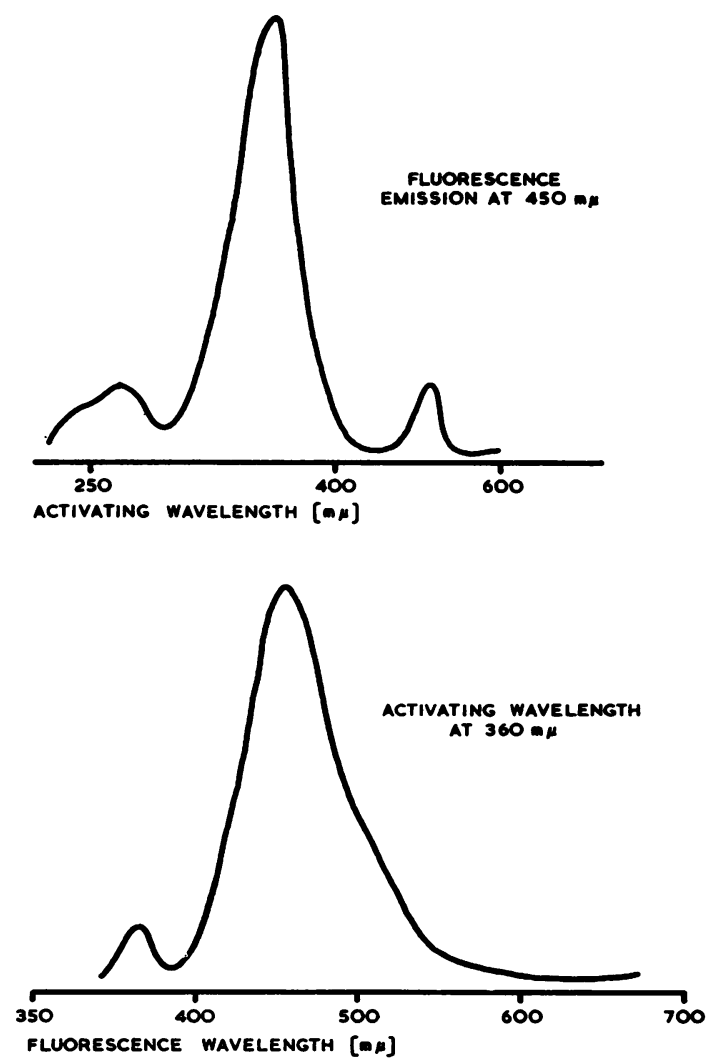

Fig. 2( $a$ and $b)$.-Activating and fluorescence spectra of 3 HAA in ethanol (Aminco-Bowman spectrofluorimeter). 
As a simple method suitable for measuring 3HAA in a large number of specimens was required, the procedure used throughout this study was essentially that of McMillan, using one-dimensional paper chromatography and visual assessment of fluorescence compared with a set of standards of 3HAA. Recovery experiments with this technique were satisfactory.

\section{Reagents}

A stock solution of 3HAA (Roche Products Ltd.) was prepared by dissolving the acid, $1 \mathrm{mg} . / \mathrm{ml}$., in ethanol made $0.01 \mathrm{~N}$ to hydrochloric acid. The amount of $\mathrm{HCl}$ necessary for solution was kept to a minimum as the fluorescence decreased with increasing acidity. Subsequent dilutions of this stock standard were made with absolute ethanol. To prepare the formate solvent for chromatography, $1 \mathrm{ml}$. formic acid (A.R.) was added to a solution of sodium formate $(10 \mathrm{~g}$.) in water $(200 \mathrm{ml}$.).

\section{Extraction Procedure}

From the 24-hr collections of urine, samples of 50 to $100 \mathrm{ml}$. depending on concentration, were made acid ( $\mathrm{N}$ w.r.t. $\mathrm{HCl}$ ) and were then extracted four times with 50-ml. portions of diethyl ether (A.R.). These combined ether extracts were discarded. The remaining aqueous solutions were adjusted to $\mathrm{pH} 3.5$ by the addition of $10 \mathrm{~N}$ sodium hydroxide and again extracted four times with $50-\mathrm{ml}$. volumes of ether. These combined ether extracts were evaporated to dryness in an all-glass still, and the residue, used for subsequent chromatography, was dissolved in $1 \mathrm{ml}$. ethanol $(0.002 \mathrm{~N}$ w.r.t. $\mathrm{HCl})$. The extract thus obtained contains free or unconjugated 3HAA. "Total" 3HAA was extracted in the same way after acid hydrolysis of the urine. Following addition of an equal volume $(50 \mathrm{ml}$.) of concentrated $\mathrm{HCl}$, the urine was boiled under a reflux condenser for one hour. Hydrolysis in $5 \mathrm{~N} \mathrm{HCl}$ is necessary to break down hippurates (Tompsett, 1961b) and was regarded as sufficient to provide a measure of total 3HAA excreted. Recovery of added 3HAA was possible in these circumstances.

\section{Chromatography}

Ascending chromatograms were run in the formate (see under Reagents) for approximately $2 \mathrm{hrs}$ at room temperature, using volumes of extract ranging from $1 \cdot 25$ to $10 \mu \mathrm{l}$. The stock standard solution of 3HAA was diluted 1 in 5 with absolute ethanol and spots of 5 and $2.5 \mu \mathrm{l}$. (containing 0.5 and $0.25 \mu \mathrm{g}$. 3HAA respectively) were applied at the origin. A spot containing standard plus extract was always run to confirm identity of the acid. On completion of the run the papers were dried and then viewed under a mercury vapour lamp having a Wood's glass filter (Osram $125 \mathrm{~W}$ MBW/U, maximum emission at 3,600 $\mathrm{m} \mu$ ). Replicate analysis of one sample of urine four times gave identical results.

\section{Recovery Experiments}

To cover the range of experimental values 3HAA ( $1 \mathrm{mg}$. $/ \mathrm{ml}$. in $\mathrm{N} \mathrm{HCl}$ ) in quantities of 50 to $400 \mu \mathrm{g}$. was added to 50-ml. samples of urine. Extracts were then prepared and chromatographed as above. Recovery experiments on acid hydrolysed urine were also carried out, 3HAA being added before hydrolysis. The results are presented in Fig. 3.

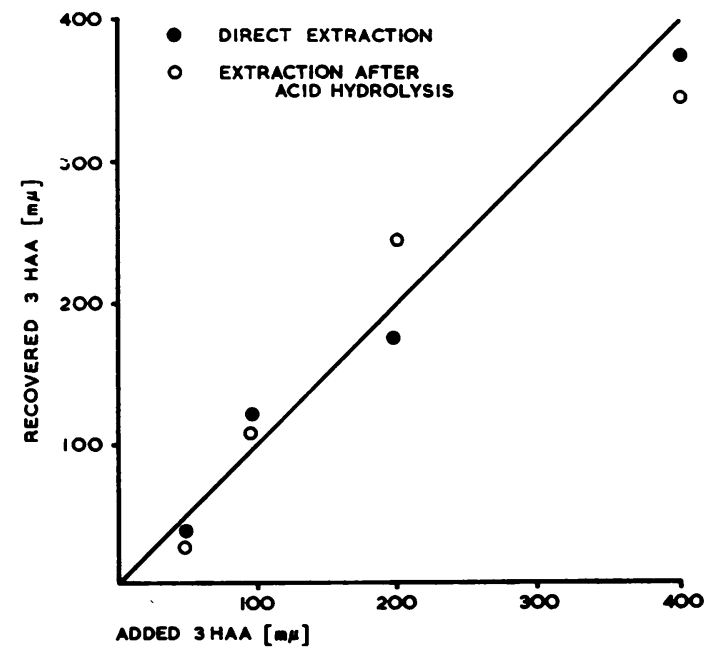

Fig. 3.-Recovery of 3 HAA added to urine.

\section{Measurement of Kynurenine}

Kynurenine was measured in 10-ml. aliquots of urine hydrolysed for $1 \mathrm{hr}$ with $\mathrm{N} \mathrm{HCl}$. The method used was a colorimetric modification (Tompsett, 1959a) of the method described by Špaček (1954).

In a small series of patients with rheumatoid arthritis, the excretion of kynurenine in $24 \mathrm{hrs}$ was measured on several successive days. These results, shown in the Table, indicate that excretion was fairly constant from day to day. Spaček (1955) has reported that the concentration of kynurenine in urine does not vary by more than 13 per cent. from day to day.

\section{TABLE}

\section{DAILY KYNURENINE EXCRETION IN FIVE PATIENTS}

\begin{tabular}{|c|c|c|c|c|c|}
\hline Patient No. & 1 & 2 & 3 & 4 & 5 \\
\hline $\begin{array}{l}\text { Daily } \\
\text { Kynurenine } \\
\text { Excretion } \\
\text { (mg./24 hrs) }\end{array}$ & $\begin{array}{l}2.7 \\
2.3 \\
2.4 \\
2.4 \\
4.9 \\
2.6 \\
3.5 \\
2.9\end{array}$ & $\begin{array}{l}6 \cdot 3 \\
6 \cdot 4 \\
= \\
= \\
= \\
=\end{array}$ & $\begin{array}{l}3 \cdot 5 \\
3 \cdot 7 \\
= \\
= \\
= \\
=\end{array}$ & $\begin{array}{l}1.9 \\
1.9 \\
2.1 \\
1.9 \\
= \\
=\end{array}$ & $\begin{array}{l}0.7 \\
0.5 \\
1.1 \\
1.0 \\
1.1 \\
= \\
=\end{array}$ \\
\hline Mean .. & $2 \cdot 9$ & $6 \cdot 3$ & $3 \cdot 6$ & $2 \cdot 0$ & 0.9 \\
\hline
\end{tabular}




\section{Results}

Excretion of free 3HAA was measured in 39 patients suffering from rheumatoid arthritis and in 25 control subjects (Fig. 4). Excretion in the controls ranged from 0 to 590 (mean 240) $\mu \mathrm{g} . / 24 \mathrm{hrs}$, and in the rheumatoid patients from 0 to 2,970 (mean 750) $\mu \mathrm{g} . / 24 \mathrm{hrs}$. In the control series there appeared to be no difference in excretion between the ambulant normal subjects and the recumbent orthopaedic patients. These findings are in agreement with those of McMillan.

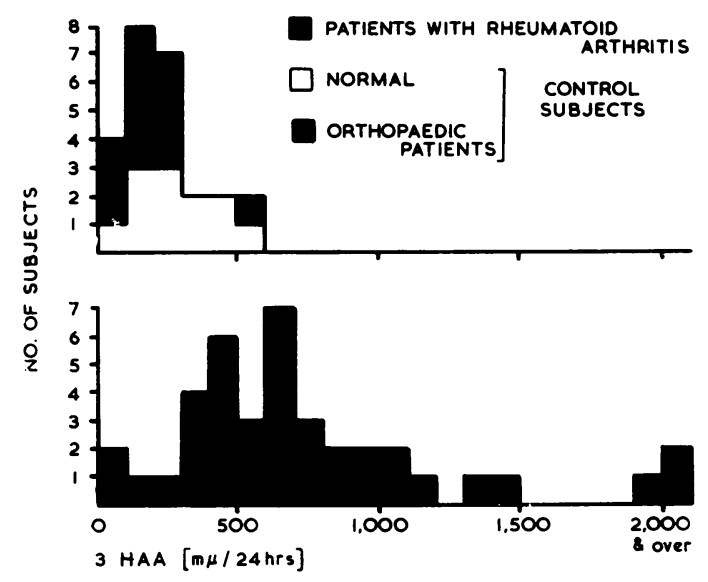

Fig. 4.-Excretion of free $3 \mathrm{HAA}$ in control subjects and patients with rheumatoid arthritis.

Excretion of free 3HAA was measured in 22 patients and fifteen control subjects in the 24-hr period after ingestion of $3 \mathrm{~g}$. DL tryptophan; the results are shown in Fig. 5. In the controls the excretion values were 940 to 4,900 (mean 1,830 ) $\mu \mathrm{g} . / 24 \mathrm{hrs}$ and in the patients with rheumatoid arthritis they were 380 to 5,280 (mean 2,220) ug. $/ 24$ hrs.

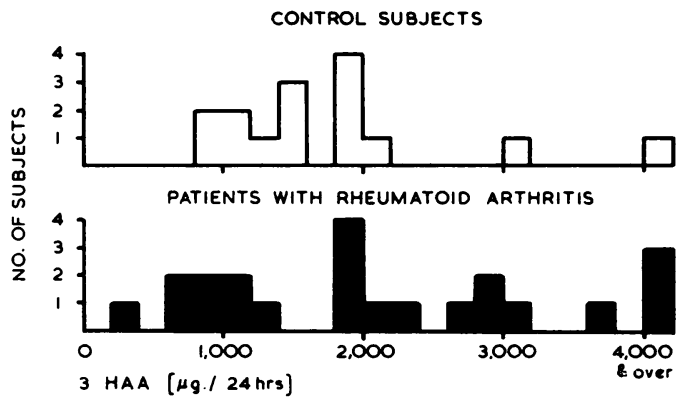

Fig. 5.- Excretion of free $3 \mathrm{HAA}$ in control subjects and patients with rheumatoid arthritis in the $24 \mathrm{hrs}$ after ingestion of $3 \mathrm{~g}$. DL tryptophan.

In the 24 hrs after taking $1 \mathrm{~g}$. D tryptophan, three subjects (two normal and one with rheumatoid arthritis) showed no increase in 3HAA output. After taking $3 \mathrm{~g}$. L tryptophan, the excretion of free 3HAA was increased to the same extent as after an equal amount of the DL form in two patients with $\stackrel{\oplus}{+}$ rheumatoid arthritis and three control subjects.

Excretion of "total" 3HAA was measured in $\frac{\bar{\sigma}}{\overline{0}}$ thirteen patients with rheumatoid arthritis and nine $\frac{\bar{\rho}}{\bar{D}}$ control subjects, while on a normal diet and also® after taking $3 \mathrm{~g}$. DL tryptophan (Figs $6 a$ and $b$ ). ొొ The controls excreted from 570 to 2,190 (mean $\overrightarrow{0}$ $1,230) ! \mathrm{g} . / 24 \mathrm{hrs}$ while on a normal diet, and from. 2,200 to 7,080 (mean 5,095) $\mu \mathrm{g} . / 24 \mathrm{hrs}$ after taking $\vec{\omega}$ $3 \mathrm{~g}$. DL tryptophan. In patients with rheumatoid arthritis, the range while on a normal diet was $830 \frac{\Omega}{\alpha}$ to 4,180 (mean 2,388 ) $\mu \mathrm{g}$. $/ 24 \mathrm{hrs}$, and 4,720 to 11,560 ĩ (mean 7,332) $\mu \mathrm{g} . / 24 \mathrm{hrs}$ after taking $3 \mathrm{~g} . \mathrm{DL}:$ tryptophan.

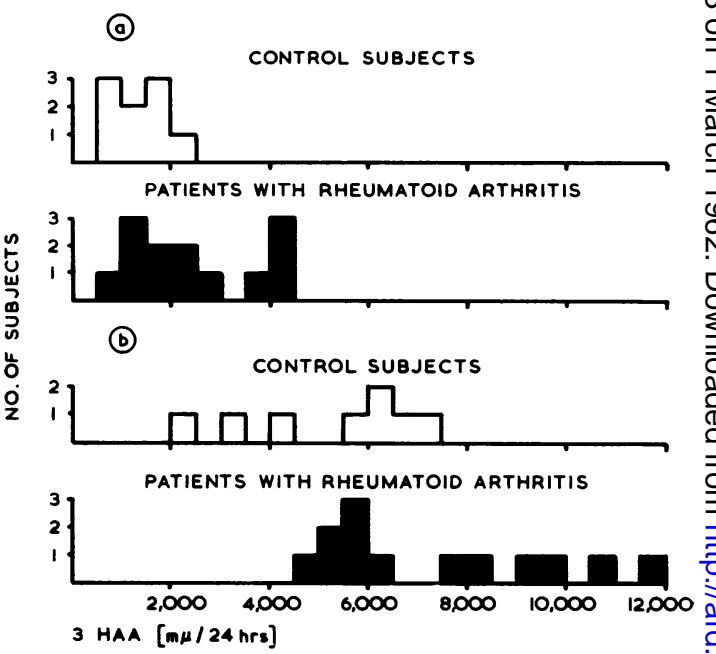

Fig. 6.-Excretion of total $3 \mathrm{HAA}$ in control subjects and patients with rheumatoid arthritis. (a) On a normal diet; (b) After $3 \mathrm{~g}$. DL tryptophan.

In some rheumatoid patients and control subjects.o 3HAA excretion was measured on two days, either consecutive or several weeks apart. Duplicateo 24-hr excretion levels after taking $3 \mathrm{~g}$. DL tryptophan were also measured in a few controls. There waso a close correlation between the results of thesen successive determinations (correlation coefficient N $r \quad 0.82 ; p<0.001)$.

Kynurenine excretion was measured in fourteen control subjects and 28 patients with rheumatoid등

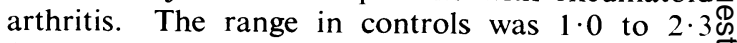
(mean 1.4) mg./24 hrs, and in the patients with rheumatoid arthritis it was 1.0 to $9 \cdot 2$ (mean $3 \cdot 2$ ) mg./24 hrs (Fig. 7, opposite).

The excretion of kynurenine after taking $3 \mathrm{~g}$. DL $\stackrel{\frac{\mathrm{O}}{\mathbb{\mathrm { D }}}}{\mathrm{O}}$ tryptophan, $1 \mathrm{~g}$. D tryptophan, and $3 \mathrm{~g}$. L tryptophan 


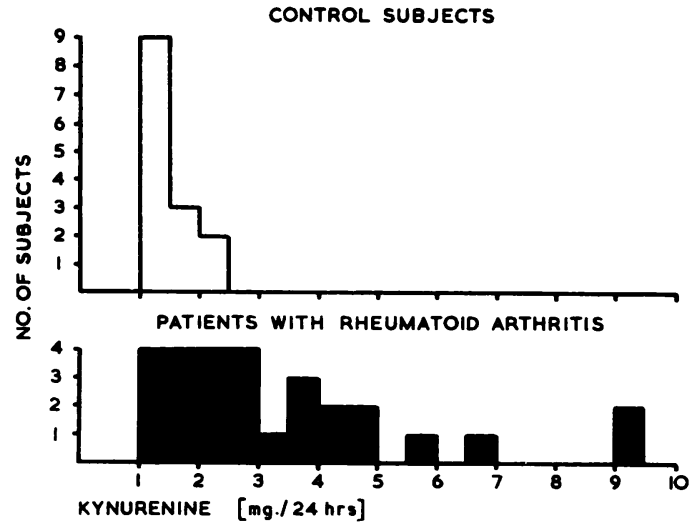

Fig. 7.-Excretion of kynurenine in control subjects and patients with rheumatoid arthritis.

was also measured in some controls and patients with rheumatoid arthritis (Fig. $8 a, b, c$ ).

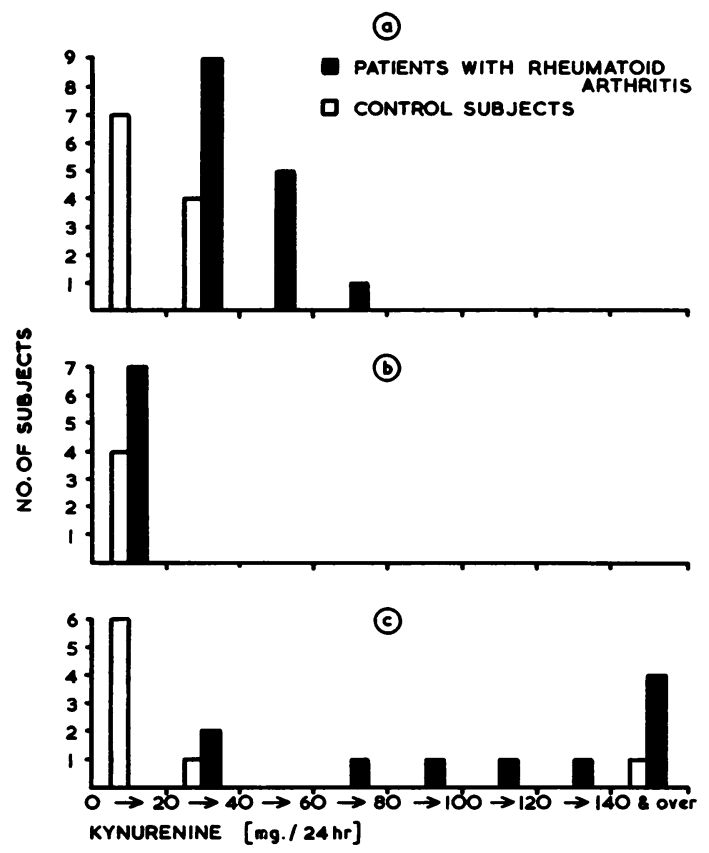

Fig. 8.-Excretion of kynurenine in control subjects and patients with rheumatoid arthritis. (a) After $3 \mathrm{~g}$. DL tryptophan; (b) After 1 g. D tryptophan; (c) After 3 g. L tryptophan.

\section{Discussion}

Obvious limitations of the method of McMillan (1960) for measuring 3HAA in urine are the final visual assessment of fluorescence and the many steps involved in the initial extraction procedure. Although it was not possible to circumvent these difficulties, the quantitative recoveries of 3HAA added to urine were reasonably good. The day-today variation in excretion by individuals may have resulted in part from limitations of the method, but it was not so great as to invalidate comparison of the results in different groups of individuals. The excretion of 3HAA in the rheumatoid patients and control subjects fell into the same pattern as that obtained by McMillan. From hydrolysis experiments there was no evidence in rheumatoid arthritis of a defective conjugation resembling that in carcinoma of the bladder postulated by Boyland and Williams (1956) from their own data.

In the tryptophan-loading experiments reported in this study, the DL form of the amino acid was used initially. In three control subjects and two patients with rheumatoid arthritis, the excretion of 3HAA after ingestion of $3 \mathrm{~g}$. DL tryptophan did not differ from the excretion after $3 \mathrm{~g}$. of the $\mathrm{L}$ isomer. Langner and Berg (1955) found that, when D tryptophan was fed to human subjects, it was largely excreted as such, although some was converted to D-kynurenine. In the present study there was no increase in excretion of 3HAA after the ingestion of $1 \mathrm{~g}$. D tryptophan in either of the two groups. The control subjects and the patients with rheumatoid arthritis all had a raised output of kynurenine after taking $\mathrm{D}$ tryptophan, but there was no difference between the groups in the excretion levels of this metabolite. The most striking difference between the two groups was in the excretion of kynurenine after a loading dose of $3 \mathrm{~g}$. L tryptophan (Fig. 8).

In the rheumatoid group there was no apparent correlation between these levels of $3 \mathrm{HAA}$ and kynurenine excretion and other parameters such as duration of disease, haemoglobin level, erythrocyte sedimentation rate, the titre of sensitized sheep cell agglutinating factor, and radiological changes. All patients with a high kynurenine output also excreted abnormally large amounts of 3HAA, but some with high 3HAA output did not excrete abnormal amounts of kynurenine.

Fig. 1 illustrates the metabolic pathways which may be relevant to the foregoing results. Although the patients with rheumatoid arthritis excreted a greater amount of 3HAA than control subjects, this difference between the two groups disappeared after tryptophan loading tests. This may indicate that any abnormality of tryptophan catabolism in rheumatoid arthritis occurs at some stage before it is degraded to 3HAA. The increased 3HAA excretion found in patients on a normal diet may then merely reflect the increased output of kynurenine and possibly of other metabolites not measured 
here. Although it has been shown that abnormal amounts of kynurenine are excreted by patients with rheumatoid arthritis on a normal diet and after tryptophan loading, it is believed that, in order to clarify the situation, excretion of other metabolites such as 3-hydroxykynurenine, kynurenic acid, and xanthurenic acid should also be measured.

Price and others (1957) have summarized some of the factors which may influence tryptophan metabolism. These include changes in tissue levels of tryptophan, alterations in the amounts of the active forms of niacin, pyridoxine, riboflavin, or thiamin in the tissues, factors affecting the activity of the pituitary-adrenal system, and alterations in the levels of metal cations which may participate in the action of pyridoxine. Jakoby and Bonner (1953a), working with Neurospora crassa, have shown that amino acids and some derivatives can act as inhibitors of kynureninase, probably by removal of pyridoxal phosphate. Pyridoxal phosphate itself is also inhibitory, probably by forming a substrate pyridoxal phosphate compound acting as an analogue type of inhibitor. It is conceivable, then, that abnormalities in the metabolism of other amino acids might also lead to abnormal excretion of tryptophan metabolites.

In the paper quoted above, Price and others (1957) reported an increased urinary excretion of kynurenine, acetyl kynurenine, 3-hydroxykynurenine, and kynurenic acid after the administration of $2 \mathrm{~g}$. L tryptophan to three patients with scleroderma. The excretion of these metabolites returned to near normal after administration of pyridoxine and/or the sodium salt of ethylenediaminetetraacetic acid. Pyridoxal phosphate probably functions in the form of a complex with a metal ion, possibly magnesium (Jakoby and Bonner, 1953b), and Price, Brown, and Ellis (1956) therefore postulated that the defect in scleroderma might be related to the abnormal mineral metabolism found in this disease. They showed that the abnormal pattern of tryptophan metabolites excreted by these patients was very different from the abnormalities previously observed by them in patients with tuberculosis treated with isoniazid and deoxypyridine. These abnormalities in excretion could be corrected by the administration of pyridoxine alone. It is hoped to extend this present work to study the effect of pyridoxine on the excretion of tryptophan metabolites in patients with rheumatoid arthritis.

\section{Summary}

McMillan's finding that the urinary excretion of 3-hydroxyanthranilic acid (3HAA) is raised in patients with rheumatoid arthritis has been con- firmed. It has been shown that this is not due to $a$ defective conjugation of the acid by these patients.

Kynurenine excretion has been measured in $\vec{c}$ series of controls and rheumatoid patients. Excre? tion of this metabolite of tryptophan was found to be higher in the rheumatoid patients than in the्ष controls.

The effect of loading doses of DL, L, and $D^{\mathbb{D}}$ tryptophan on the excretion of 3HAA and kynurees nine has been studied in a series of controls an 5 rheumatoid patients. D tryptophan was not con:verted to 3HAA by any of the subjects. After ingestion of $\mathrm{L}$ tryptophan, the level of 3HAA excretion was raised both in the controls and the rheumatoid patients. There was no difference in these excretion levels between the two groups.

Kynurenine excretion was raised in all subject after ingestion of all three forms of tryptophano After ingestion of $D$ tryptophan, the rise was moder? ate and there was no difference in excretion between the two groups.

After ingestion of $\mathrm{L}$ tryptephan there was a large increase in kynurenine excretion in the patients with rheumatoid arthritis, but only a moderate increase in the control group.

This research was supported by a grant from the Medical Research Council to Dr. J. J. R. Duthie ande during the period in which it was carried out, th Rheumatic Diseases Unit was also in receipt of grants from the Nuffield Foundation, the Empire Rheumatisn Council, and Boots Pure Drug Company Ltd.

I am grateful to Dr. J. J. R. Duthie and Dr. J. L. Potter for their helpful advice and criticism.

\section{REFERENCES}

Allen, M. J., Boyland, E., Dukes, C. E., Horning, E. S and Watson, J. G. (1957). Brit. J. Cance? 11, 212.

Altman, K. I., and Miller, G. (1953). Nature (Lond.) 172,868

Boyland, E., and Williams, D. C. (1956). Biochem. J 64, 578 .

Coppini, D., Benassi, C. A., and Montorsi, M. (1959 $\mathrm{W}$ Clin. Chem., 5, 391.

Dalgliesh, C. E. (1952). Biochem. J., 52, 3. (1955a). Ibid., 61, 328.

_ (1955b). J. clin. Path., 8, 73.

Jakoby, W. B., and Bonner, D. M. (1953a). J. biot Chem., 205, 709.

—, - (1953b). Ibid., 205, 699.

Langner, R. R., and Berg, C. P. (1955). Ibid., 214, 699.

McMillan, M. (1960). J. clin. Path., 13, 140.

Musajo, L., Benassi, C. A., and Parpajola, A. $\left(1956 \frac{\mathrm{P}}{\mathrm{D}}\right.$ Clin. chim. Acta, 1, 229. Spada, A., and Coppini, D. (1952). J. bio Chem., 196, 185. 
Oka, M., and Leppänen, V. V. E. (1959). Ann. rheum. Dis., 18, 313.

Price, J. M., Brown, R. R., and Ellis, M. E. (1956). J. Nutr., 60, 323.

—- —, Rukavina, J. G., Mendelson, C., and Johnson, S. A. M. (1957). J. invest. Derm., 29, 289.

Špaček, M. (1954). Canad. J. Biochem., 32, 604. (1955). Ibid., 33, 14.

Tompsett, S. L. (1959a). Clin. chim. Acta, 4, 411. (1959b). Analyt. chim. Acta, 21, 555.

(1961a). Ibid., 24, 438.

(1961b). J. Pharm. Pharmacol., 13, 115.

Wiseman, M. H., Kalant, N., and Hoffman, M. M. (195i). J. Lab. clin. Med., 52, 27.

\section{Métabolisme du tryptophane dans l'arthrite rhumatismale} RÉSUMÉ

On confirme la découverte de McMillan que l'excrétion de l'acide 3-hydroxyanthralinique (3 HAA) est augmentée chez des malades atteints d'arthrite rhumatismale. Il est démontré que cela n'est pas dû à un défaut de conjugaison de l'acide chez ces malades.

On a mesuré l'excrétion de kyurénine dans une série de malades rhumatisants et de témoins. L'excrétion de ce métabolite de tryptophane était plus grande chez les rhumatisants que chez les témoins.

On a étudié chez des malades atteints d'arthrite rhumatismale et chez des témoins l'effet de massives doses de tryptophane DL, L et D sur l'excrétion de 3 HAA et de kyurénine. Le tryptophane D n'était transformé en 3 HAA par aucun sujet. Après l'ingestion de tryptophane L, le taux d'excrétion de 3 HAA était augmenté chez les témoins et chez les rhumatisants. Il n'y avait pas de différence dans le taux d'excrétion entre les deux groupes.

L'excrétion de kyurénine était augmentée chez tous les sujets après l'ingestion de toutes les formes de tryptophane. Après l'ingestion de tryptophane D, l'augmentation était modérée et il n'y avait pas de différence entre les deux groupes.

Après l'ingestion de tryptophane $\mathbf{L}$, il s'est produit une forte augmentation de l'excrétion de kyurénine chez des malades atteints d'arthrite rhumatismale, alors que chez des témoins cette augmentation n'était que modérée.

El metabolismo del triptófano en la artritis reumatoide

\section{Sumario}

Se confirmó la descubierta de McMillan que la excreción del ácido 3-hidroxiantralínico (3HAA) se ve aumentada en enfermos con artritis reumatoide. Queda demostrado que este hecho no se debe a un defecto de conjugación del ácido en estos enfermos.

Se midió la excreción de kyurenina en una serie de enfermos con artritis reumatoide $y$ de testigos. La excreción de este metabólito de triptófano fué mayor en los enfermos que en los testigos.

En enfermos con artritis reumatoide y en testigos se estudió el efecto de dosis fuertes de triptófano DL, L y D sobre la excreción de 3 HAA y de kyurenina. El triptófano $\mathrm{D}$ no fué transformado en $3 \mathrm{HAA}$ por ningun sujeto. Despuès de la ingestión de triptófano $\mathrm{L}$, la excreción de 3HAA aumentó tanto en los testigos como en los enfermos reumatoides. No hubo diferencia en las tasas de excreción entre ambos grupos.

La excreción de kyurenina fué aumentada en todos los sujetos despuès de la ingestión de todas las formas de triptófano. Después de la ingestión del triptófano $\mathrm{D}$, el aumento fué moderado y no hubo diferencia entre el uno y el otro grupo.

Después de la ingestión del triptófano $\mathbf{L}$, se produjo una fuerte aumentación de la excreción de kyurenina en los enfermos con artritis reumatoide, mientras que en los testigos este aumento no fué más que moderado. 